Study. Am J Respir Crit Care Med 2002;166:333-9

6 Sin DD, Wu L, Anderson JA, et al. Inhaled corticosteroids and mortality in chronic obstructive pulmonary disease. Thorax 2005;60:992-7.

7 Sin DD, McAlister FA, Man SF, et al. Contemporary management of chronic obstructive pulmonary disease: scientific review. JAMA 2003;290:2301-12.

8 Sin DD, Jones RL, Mannino DM, et al. Forced expiratory volume in 1 second and physical activity in the general population. Am J Med 2004; 117:270-3.

9 Montes de Oca M, Rassulo J, Celli BR. Respiratory muscle and cardiopulmonary function during exercise in very severe COPD. Am J Respir Crit Care Med 1996;154:1284-9.

10 Schols AM, Broekhuizen R, Weling Scheepers CA, et al. Body composition and mortality in chronic obstructive pulmonary disease. Am J Clin Nutr 2005;82:53-9.

11 Marquis K, Debigare R, Lacasse Y, et al. Midthigh muscle cross-sectional area is a better predictor of mortality than body mass index in patients with chronic obstructive pulmonary disease. Am J Respir Crit Care Med 2002;166:809-13.

12 Mador MJ, Bozkanat E. Skeletal muscle dysfunction in chronic obstructive pulmonary disease. Respir Res 2001 ;2:216-24.

13 Agusti AG, Sauleda J, Miralles C, et al. Skeletal muscle apoptosis and weight loss in chronic obstructive pulmonary disease. Am J Respir Crit Care Med 2002; 166:485-9.

14 Agusti A, Morla M, Sauleda J, et al. NF-kappaB activation and iNOS upregulation in skeletal muscle of patients with COPD and low body weight. Thorax 2004;59:483-7.

15 Yende S, Waterer GW, Tolley EA, et al. Intlammatory markers are associated with ventilatory limitation and muscle dysfunction in obstructive lung disease in well functioning elderly subjects. Thorax 2006;61:10-16.

16 Broekhuizen R, Wouters EF, Creutzberg EC, et al. Raised CRP levels mark metabolic and functional impairment in advanced COPD. Thorax 2006;61:17-22

17 Pinto-Plata VM, Mullerova H, Toso JF, et al. $\mathrm{C}$-reactive protein in patients with COPD, control smokers, and non-smokers. Thorax 2006;61:23-8.

18 Gan WQ, Man SF, Senthilselvan A, et al. Association between chronic obstructive pulmonary disease and systemic inflammation: a systematic review and a meta-analysis. Thorax 2004;59:574-80.

19 Tice JA, Browner W, Tracy RP, et al. The relation of $C$-reactive protein levels to total and cardiovascular mortality in older US women. Am J Med 2003;1 14:199-205.

20 Redelmeier DA, Bayoumi AM, Goldstein RS, et al. Interpreting small differences in functional status: the six minute walk test in chronic lung disease patients. Am J Respir Crit Care Med 1997; 155:1278-82

21 Sin DD, Lacy P, York E, et al. Effects of fluticasone on systemic markers of inflammation in chronic obstructive pulmonary disease. Am J Respir Crit Care Med 2004:170:760-5.

22 Gan WQ, Man SF, Sin DD. Effects of inhaled corticosteroids on sputum cell counts in stable chronic obstructive pulmonary disease: a systematic review and a meta-analysis. BMC Pulm Med 2005;5:3.

23 Latronico N, Peli E, Botteri M. Critical illness myopathy and neuropathy. Curr Opin Crit Care 2005; 11:126-32.

24 Ladner KJ, Caligiuri MA, Guttridge DC. Tumor necrosis factor-regulated biphasic activation of NF-kappa B is required for cytokine-induced loss of skeletal muscle gene products. J Biol Chem 2003;278:2294-303.

25 De Benedetti F, Alonzi T, Moretta A, et al. Interleukin 6 causes growth impairment in transgenic mice through a decrease in insulin like growth factor 1. J Clin Invest 1997; 15:643-50.

26 Musaro A, McCullagh K, Paul A, et al. Localized lgf-1 transgene expression sustains hypertrophy and regeneration in senescent skeletal muscle. Nat Genet 2001;27:195-200.

27 Drexler H, Riede U, Munzel T, et al. Alterations of skeletal muscle in chronic heart failure. Circulation 1992:85:1751-9.

28 Anker SD, Coats AJ. How to RECOVER from RENAISSANCE? The significance of the results of RECOVER, RENAISSANCE, RENEWAL and ATTACH. Int J Cardiol 2002;86:123-30.

29 Chung ES, Packer M, Lo KH, et al. Randomized, double-blind, placebo-controlled, pilot trial of infliximab, a chimeric monoclonal antibody to tumor necrosis factor-alpha, in patients with moderate-to-severe heart failure: results of the anti-TNF Therapy Against Congestive Heart Failure (ATTACH) trial. Circulation 2003; 107:3133-40.
Childhood allergies, birth order and family size

\section{Childhood allergies, birth order and family size}

\section{P Cullinan}

\section{Further debate on the explanation for the association between sibship size/birth order and childhood allergic disease}

( the 10 plagues visited on the biblical Egyptians, the last was the most terrible; after the rain of frogs, the plague of boils, and the hailstorms came the indiscriminate slaughter of all firstborn animals including children. Infanticide of this degree is thankfully rare-but is it possible that the author(s) of Exodus were expressing a subtler truth?

\section{ASSOCIATIONS BETWEEN BIRTH ORDER/SIBSHIP AND DISEASE}

Studies of birth order —or sibship size—as a risk factor have a long history and have examined a wide variety of diseases. Thus, for example, the rates of Hodgkin's lymphoma in young adults, ${ }^{12}$ HBsAg+ hepatocellular cancer, ${ }^{3}$ acute lymphoblastic leukaemia, ${ }^{4}$ and type I diabetes mellitus $^{56}$ all appear to fall with increasing birth order. In each case the pattern has been assumed to reflect the relatively late age at which children of low birth order (or their mothers during pregnancy) acquire common infections. A similar (but opposite) reasoning has been applied to the observations that children of low birth order are at reduced risks of nonHodgkin's lymphoma, ${ }^{7}$ schizophrenia, ${ }^{8}$ gastric carcinoma and ulcer, ${ }^{9}$ acute myeloblastic leukaemia, ${ }^{10}$ and some congenital heart defects. ${ }^{11}$ Children of low birth order are also more likely to have infantile pyloric stenosis, to be taller, ${ }^{12}$ to be right handed $^{13}$ and, if they are male, to be heterosexual; ${ }^{14}$ these are less easily attributed to patterns of early infection.

Nowhere, however, are the patterns of birth order/sibship clearer than with the childhood respiratory allergies. First observed by Butler and Golding in $1986,{ }^{15}$ reductions in the risks of hay fever, eczema, atopy and, less consistently, asthma with increasing birth order or sibling numbers have been reported in at least 30 studies and usefully reviewed by Karmaus and Botezan. ${ }^{16}$ As with most of the diseases above, these observations have generally been attributed to different rates and timings of early (unspecified) childhood infection. Indeed, they form the cornerstone of the "hygiene hypothesis" whereby it is proposed that the risks of atopic disease are reduced by early contact with infection, ${ }^{17}$ a proposal bolstered by the more recent suggestion that children born to Alpine farmers are protected in a similar manner.

\section{ASSOCIATION BETWEEN SIBSHIP SIZE/BIRTH ORDER AND ALLERGIC DISEASE}

In this issue of Thorax, Kinra et $a l^{18}$ provide an historical perspective on the associations between allergic disease and sibship size/birth order. Their population comprised 14000 students, predominantly male and about $50 \%$ of those eligible, who were screened at Glasgow University between 1948 and 1968. The students had a mean age of 19 years and were born between 1918 and 1952; for the purposes of this analysis, they were divided into three equally spaced birth cohorts. Intriguingly, there was no increase in the prevalence of self-reported allergic disease across the time frame of the three cohorts, although it is difficult to judge how representative this finding might be. The authors found clearly decreasing trends in reported allergic 
diseases (especially hay fever) with both increasing family size and birth order. Although the differences were small and are readily explained by chance, the effects were strongest in the earliest cohort. If this is explained by greater interfamily differences in infection in that era, then the findings overall are compatible with a "hygiene explanation". Further support is provided by the finding that allergic diseases were less common among students from less affluent backgrounds, and by a (weak) interaction between birth order (but not family size) and childhood socioeconomic status. The report is valuable because it suggests that the sibship/ birth order phenomenon is temporally robust and thus indicative of a relatively era independent mechanism.

\section{HYGIENE HYPOTHESIS}

As an explanation of family size effects (especially where these have been related to older siblings) and of other aspects of the epidemiology of childhood allergies (notably its geographical distribution), the hygiene hypothesis is both plausible and parsimonious. ${ }^{19}$ There are, however, increasing doubts that it is a complete explanation. First is the very tenacity of the birth order/ sibship observation. This, of course, is not in itself a counterargument, but consistency is unusual in the shifting sands of asthma epidemiology. If early contact with infection alone is crucial in the development of childhood allergy, then one might expect the effects of the surrogate of family size to have changed more clearly with shifts in the patterns of early infection. This does not appear to be the case. It is not even clear whether the rates and timings of childhood infections are indeed closely related to family structure in the heavily immunised small family societies where allergic diseases are so prevalent. Even in rural Poland where the prevalence of atopy is extremely low-presumably as a result of extensive microbial contact in early childhood-we have recently observed a clearly increased risk among firstborn children. Attempts to explain sibship effects by direct measurement of early infection have not been successful, ${ }^{2021}$ although this may reflect the poverty of our methods of measuring the subtleties of "infective load".

Equally as striking as its consistency is the strength of the effect. With the exception of family history and, in certain communities, a farming childhood, no other risk factors have been identified as being so powerful. There is, furthermore, a paucity of supporting analogous evidence. Studies of child care, for example-a surrogate for a large family-have produced inconsistent results, ${ }^{22}$ and those that have examined the early use of antibiotics have found no consistent evidence that these are harmful. ${ }^{23}$ Interestingly, even in classical infectious disease epidemiology the logic that birth order determines age of first infection and thus outcome is not always clear. $^{24}$

Birth order and family size are inevitably correlated, especially when average family sizes are small. Distinguishing the effects of the two has proved to be very difficult and probably requires the use of large populations. Nonetheless, they may be indicative of different mechanisms. Children at the head of a sibship differ from others in ways that do not necessarily reflect their infectious experience. On the whole they are more often male, are born to younger parents, are of lower birth weight, and are more frequently from "abbreviated" families. Traditionally, children from small families have been from higher socioeconomic groups. Patterns of breast feeding may be related to birth order or family size as, intriguingly, may early exposures to domestic allergens. ${ }^{25}$ Parents' reporting of their children's illnesses is likely to be heavily influenced by their level of previous experience. Studies of sibship effects need to consider each of these potentially confounding variables and to be aware that, on cross sectional analysis (the most common design used in asthma epidemiology), the probability of a child being in any particular birth position is dependent on time related changes in family size. ${ }^{26}$

\section{OTHER POSSIBLE EXPLANATIONS}

If variations in the pattern of early infection are not the whole explanation of the sibship effects in childhood allergies, what other explanations are there? Levels of IgE in cord blood are lower in multiparous women, as is the specific reactivity of cord blood mononuclear cells. ${ }^{27} 28$ These findings may reflect higher rates of in utero infection of women who already have other children or, at least in the latter instance, higher maternal age. Alternatively, they may reflect the maternal experience of pregnancy itself. Pregnancy is an immunological challenge to the mother and child and it may be that the complex mechanisms associated with fetal survival vary systematically with increasing parity. These may, in turn, be reflected by shifts in maternal immunity. Women (but not men) who have had several children are less likely to be atopic, an observation that is not explained by age, ${ }^{29}$ and they are less likely than nulliparous women to report symptoms consistent with allergic rhinitis $^{30}$ or conjunctivitis. ${ }^{31}$ When studied prospectively, women who have had more pregnancies are more likely to "lose" their atopic state and their hay fever than are women who have had no (further) pregnancies. ${ }^{32}$ Some have suggested that these apparent shifts in maternal immunity are hormone related. ${ }^{33}$ It remains unclear how and whether they are transmitted to successive children, although there is some evidence that firstborn children respond differently to respiratory allergens encountered in the first weeks of life. ${ }^{34}$

Further attention to non-infectious explanations for the sibship effects in childhood allergy seems warranted. A useful starting point might be the experience of other diseases: for many years it has been known that the risks of pre-eclampsia fall sharply with parity but return to baseline when a woman is pregnant through a new partner. Paternity has not, as far as I am aware, been examined in the development of respiratory allergies. If nothing more, it might shed some light on the muddled area of parental inheritance.

The public health implications of a sibship effect that is not attributable solely to "hygiene" are not easily envisaged. After all, firstborn children cannot be avoided, but it may be that a better understanding of the nature of their risk will allow the more effective targeting of preventive strategies; and it may be time to revisit the discredited argument that changes in family structure have been an important part of the late 20th century epidemic of childhood allergies.

Thorax 2006;61:3-5.

doi: 10.1136/thx.2004.039701

Correspondence to: Dr P Cullinan, Department of Occupational and Environmental Medicine, Imperial College School of Medicine at the National Heart and Lung Institute, London SW3 6LR, UK; p.cullinan@imperial.ac.uk

\section{REFERENCES}

1 Gutensohn N, Cole P. Childhood social environment and Hodgkin's disease. N Engl J Med 1981;304:135-40.

2 Westergaard T, Melbye M, Pedersen JB, et al. Birth order, sibship size and risk of Hodgkin's disease in children and young adults: a population-based study of 31 million personyears. Int J Cancer 1997;72:977-81.

3 Hsieh CC, Tzonou A, Zavitsanos X, et al. Age at first establishment of chronic hepatitis $B$ virus infection and hepatocellular carcinoma risk. A infection and hepatocellular carcin
birth order study. Am J Epidemiol 1992;136:1115-21.

4 Westergaard T, Andersen PK, Pedersen JB, et al. Birth characteristics, sibling patterns, and acute leukemia risk in childhood: a population-based cohort study. J Natl Cancer Inst 1997;89:939-47.

5 Bingley PJ, Douek IF, Rogers CA, et al. Influence of maternal age at delivery and birth order on risk of type 1 diabetes in childhood: prospective population based family study. Bart's-Oxford Family Study Group. BMJ 2000;321:420-4. 
6 McKinney PA, Okasha M, Parslow RC, et al. Early social mixing and childhood type 1 diabetes mellitus: a case-control study in Yorkshire, UK Diabet Med 2000; 17:236-42.

7 Grulich AE, Vajdic CM, Kaldor JM, et al. Birth order, atopy, and risk of non-Hodgkin lymphoma. J Natl Cancer Inst 2005;97:587-94.

8 Sham PC, MacLean CJ, Kendler KS. Risk of schizophrenia and age difference with older siblings. Evidence for a maternal viral infection hypothesis? Br J Psychiatry 1993;163:627-33.

9 Blaser MJ, Chyou PH, Nomura A. Age at establishment of Helicobacter pylori infection and gastric carcinoma, gastric ulcer, and duodenal ulcer risk. Cancer Res 1995; 55:562-5.

10 Westergaard T, Andersen PK, Pedersen JB, et al. Birth characteristics, sibling patterns, and acute leukemia risk in childhood: a population-based cohort study. J Natl Cancer Inst 1997;89:939-47.

11 Zhan SY, Lian ZH, Zheng DZ, et al. Effect of fathers' age and birth order on occurrence of congenital heart disease. J Epidemiol Community Health 1991;45:299-301.

12 Kuh D, Wadsworth M. Parental height: childhood environment and subsequent adult height in a national birth cohort. Int J Epidemiol 1989; 18:663-8

13 Tan LE, Nettleton NC. Left handedness, birth order and birth stress. Cortex 1980;16:363-73.

14 Zucker KJ, Blanchard R, Siegelman M. Birth order among homosexual men. Psychol Rep 2003;92:117-8.
15 Butler NR, Golding J. From birth to five: a study of the health and behaviour of Britain's 5 year olds. Oxford: Pergamon Press, 1986

16 Karmaus W, Botezan C. Does a higher number of siblings protect against the development of allergy and asthma? A review. J Epidemiol Community Health 2002:56:209-17.

17 Strachan DP. Hay fever, hygiene, and household size. BMJ 1989;299:1259-60.

18 Kinra S, Davey Smith G, Jeffreys $M$, et al. Association between sibship size and allergic diseases in the Glasgow Alumni Study. Thorax 2006;61:48-53.

19 Strachan DP. Family size, infection and atopy: the first decade of the "hygiene hypothesis". Thorax 2000;55(Suppl 1):S2-10.

20 McKeever TM, Lewis SA, Smith C, et al. Siblings, multiple births, and the incidence of allergic disease: a birth cohort study using the West Midlands general practice research database. Thorax 2001;56:758-62.

21 Cullinan P, Harris JM, Newman Taylor AJ, et al. Can early infection explain the sibling effect in adult atopy? Eur Respir J 2003;22:956-61.

22 Nystad W. Daycare attendance, asthma and atopy. Ann Med 2000;32:390-6.

23 Cullinan P, Harris J, Mills P, et al. Early prescriptions of antibiotics and the risk of allergic disease in adults: a cohort study. Thorax 2004;59:11-5.

24 Nielsen NM, Aaby P, Wohlfahrt J, et al. The polio model. Does it apply to polio? Int J Epidemio 2002;31:181-6.
25 Atkinson W, Harris J, Mills P, et al. Domestic aeroallergen exposures among infants in an English town. Eur Respir J 1999;13:583-9.

26 James WH. Multiple sclerosis and birth order. J Epidemiol Community Health 1984;38:21-2

27 Devereux G, Barker RN, Seaton A Antenatal determinants of neonatal immune responses to allergens. Clin Exp Allergy 2002;32:43-50

28 Karmaus W, Arshad H, Mattes J. Does the sibling effect have its origin in utero? Investigating birth order, cord blood immunoglobulin E concentration, and allergic sensitization at age 4 years. Am J Epidemiol 2001;154:909-15.

29 Sunyer J, Anto JM, Harris J, et al. Maternal atopy and parity. Clin Exp Allergy 2001:31:1352-5.

30 Westergaard T, Begtrup K, Rostgaard K, et al. Reproductive history and allergic rhinitis among 31145 Danish women. Clin Exp Allergy 2003:33:301-5.

31 Forastiere F, Sunyer J, Farchi S, et al. Number of offspring and maternal allergy. Allergy 2005;60:510-4

32 Harris JM, White C, Moffat S, et al. New pregnancies and loss of allergy. Clin Exp Allergy 2004;34:369-72

33 Rangaraj S, Doull I. Hormones not hygeine? Birth order and atopy. Clin Exp Allergy 2003:33:277-8.

34 Cullinan $\mathbf{P}$, MacNeill SJ, Harris JM, et al. Early allergen exposure, skin prick responses, and atopic wheeze at age 5 in English children: a cohort study. Thorax 2004;59:855-61.

In view of the known limitations of chest radiography for pulmonary nodule detection compared with spiral CT scanning, it would seem sensible to be concerned about an increase in overdiagnosis using the more sensitive technology.

\section{LUNG CANCER AND NODULE DETECTION}

The initial reports on the use of LDDCT scanning in screening for lung cancer have confirmed its ability to detect early stage lung cancer and its superiority in detection compared with chest radiography. ${ }^{6-10}$ The study most discussed is the Early Lung Cancer Action Project (ELCAP), a non-randomised prospective analysis of LDDCT scanning in which 27 lung cancers were detected in 1000 participants using LDDCT compared with seven using chest radiography. ${ }^{6}$ ELCAP also reported increased detection of non-calcified nodules (NCNs) using LDDCT, the majority of which were not malignant. But, perhaps the most impressive results reported by ELCAP involved the work-up of the pulmonary nodules detected, with only 28 patients having a lung biopsy, 27 of whom were confirmed to have malignancy. ${ }^{6}$

\section{COMPARISON OF STUDIES}

The difficulties in extrapolating data from one population and medical system to another are highlighted by MacRedmond et al in this issue of Thorax, ${ }^{11}$ and two studies from the USA and two from Europe are used here for
The detection of clinically unimportant disease for a particular patient-or undiagnosed" lung cancers discovere at post mortem examination. ${ }^{5}$ 